\title{
Probabilistic modelling of rainfall induced landslide hazard assessment
}

\author{
S. Kawagoe ${ }^{1}$, S. Kazama ${ }^{2}$, and P. R. Sarukkalige ${ }^{3}$ \\ ${ }^{1}$ Division of Environmental System Management, Faculty of Symbiotic Systems Science, Fukushima University, 1, \\ Kanayagawa, Fukushima, 960-1296, Japan \\ ${ }^{2}$ Department of Civil Engineering, Tohoku University, 6-6-06, Aramaki aza aoba, Aoba ku, Sendai, 980-8579, Japan \\ ${ }^{3}$ Department of Civil Engineering, Curtin University of Technology, G.P.O. Box U1987, Perth, WA 6845, Australia
}

Received: 6 January 2010 - Published in Hydrol. Earth Syst. Sci. Discuss.: 29 January 2010

Revised: 14 May 2010 - Accepted: 12 June 2010 - Published: 25 June 2010

\begin{abstract}
To evaluate the frequency and distribution of landslides hazards over Japan, this study uses a probabilistic model based on multiple logistic regression analysis. Study particular concerns several important physical parameters such as hydraulic parameters, geographical parameters and the geological parameters which are considered to be influential in the occurrence of landslides. Sensitivity analysis confirmed that hydrological parameter (hydraulic gradient) is the most influential factor in the occurrence of landslides. Therefore, the hydraulic gradient is used as the main hydraulic parameter; dynamic factor which includes the effect of heavy rainfall and their return period. Using the constructed spatial data-sets, a multiple logistic regression model is applied and landslide hazard probability maps are produced showing the spatial-temporal distribution of landslide hazard probability over Japan. To represent the landslide hazard in different temporal scales, extreme precipitation in 5 years, 30 years, and 100 years return periods are used for the evaluation. The results show that the highest landslide hazard probability exists in the mountain ranges on the western side of Japan (Japan Sea side), including the Hida and Kiso, lide and the Asahi mountainous range, the south side of Chugoku mountainous range, the south side of Kyusu mountainous and the Dewa mountainous range and the Hokuriku region. The developed landslide hazard probability maps in this study will assist authorities, policy makers and decision makers, who are responsible for infrastructural planning and development, as they can identify landslide-susceptible areas and thus decrease landslide damage through proper preparation.
\end{abstract}

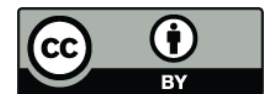

Correspondence to: P. R. Sarukkalige (p.sarukkalige@curtin.edu.au)

\section{Introduction}

Landslides are the most dangerous natural hazard in the mountainous regions of Japan. Landslides occur in different formats such as slope failures, mud flows, and mass movements. Frequent landslides often result in significant damage to people and property. Heavy rainfalls, heavy snowfalls and earthquakes, which are frequent events in Japan, are the leading causes increasing these damaging hazards. Especially, torrential downpours within short time periods, and resultant excessive increases in groundwater levels, are conducive to extensive landslides during the heavy rainfall season (Okimura et al., 1985; Iida, 1999). For example, more than 2530 landslide disasters were triggered by heavy rainfalls in 2004. This is double the annual average number of landslides in Japan (Disaster report, 2004, 2005). In addition, steep terrains and weak geological characteristics which are very common in Japan, lead to frequent landslides in the mountainous regions of Japan. Due to the extensive land use activities in Japan, some of the main infrastructure (especially buildings, railways and highways) are located in these mountainous regions. Therefore, the areas that are particularly at risk of landslides should be identified so as to reduce the probability of damage in the region. Hence, landslide hazard assessments have become a vital subject for authorities, as they can assess and predict landslide-susceptible areas and thus decrease landslide damage through proper preparation. It assists decision makers who are responsible for infrastructural development and environmental protection.

In this study, a probabilistic analysis approach is implemented in order to evaluate the landslide vulnerability over Japan, with consideration of the influences of external

Published by Copernicus Publications on behalf of the European Geosciences Union. 


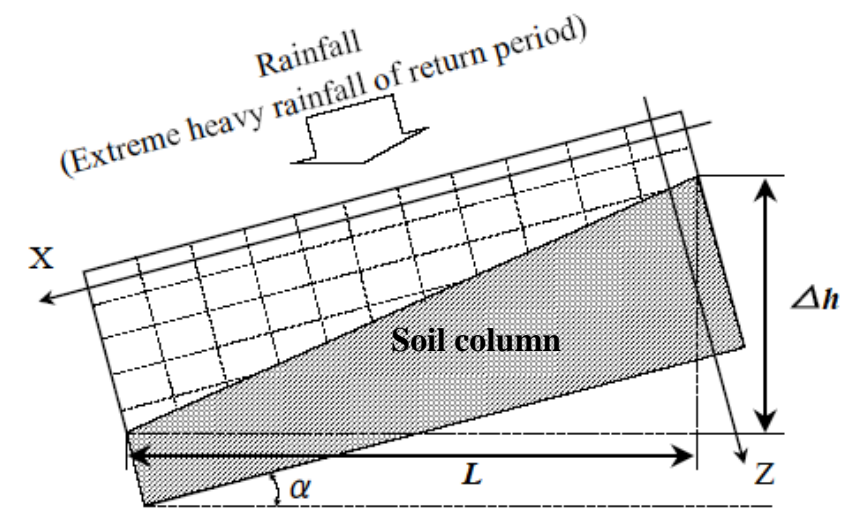

Fig. 1. Schematic diagram for infiltration analysis to obtain the hydraulic gradient.

parameters such as extreme rainfall. As rainfall is a temporal parameter, the results of this study depict the landslide hazard probability taking annual hydrological cycle and different return periods into account (Fell et al., 2006; Zezere, 2002). The advantage of using rainfall as a temporal component is not only a consideration for the cause of the landslide, but also an assessment of spatial and temporal distribution of landslide hazard vulnerability.

\section{Methods and materials}

There have been numerous studies reported in literature to determine the landslide triggering factors. Geographical and geological factors had been considered using aerial photographs, and remote sensing data (Kojima et al., 2003; Tarolli and Tarboton, 2006). Rainfall has been widely considered as the main temporal landslide triggering parameter for landslide hazrad assessments (Fell et al., 2008; Westen, 2006; Nagarajan, 2000) In this study, several identified triggering factors are categorized into groups as hydraulic factors, geological factors and geographical factors. Change in hydraulic gradient (rate of change of hydraulic head per unit distance in a particular direction) due to rainfall is considered as hydraulic factor. The relief energy (elevation difference between highest and lowest locations), slope gradient and topography are considered as the geographical factors. Four commonly available geological formations in Japan colluvium, Paleogene sedimentary rocks, Neogene sedimentary rocks, and granites represent the geological factors (Minato et al., 1965).

There have been two main approaches to evaluate landslide hazard; deterministic and statistical approaches. Wu and Sidle (1995), Gokceoglu and Aksoy (1996), Atkinson and Massari (1998), Yilmazer et al. (2003), Xie et al. (2007) presented some deterministic approaches using geotechnical methods, whereas, Temesgen et al. (2001), Lee and Min (2001), Ohlmacher and Davis (2003), Westen et al. (2003) used statistical approaches. Couple of studies tried to compare the assessments from statistical approaches and deterministic approaches and discussed their advantages and disadvantages (Calcaterra et al., 1998; Aleotti and Chowdhury, 1999; Lee et al., 2008). Deterministic approaches are based on slope stability analyses, and are only applicable when the ground conditions are fairly uniform across the study area and the landslide types are known and relatively easy to analyze (Dai et al., 2001). On the other hand, statistical approaches are indirect hazard mapping methodologies that involve statistical determination of the combinations of variables that have led to landslide occurrence in the past. Probability is the backbone of the statistical analysis. Another advantage of the probabilistic method is the possibility to use over a large area, where numerous natural slopes exist (Refice and Capolongo, 2002; Guzzetti et al., 2005; Zolfaghari and Heath, 2008; Shou et al., 2009). Thus, the use of probabilistic methods has become an important aspect in assessing landslide hazard where the probability, location, and frequency of future landslides can be predicted using landslide hazard maps.

In this study, we have mainly followed the statistical approach for the evaluation. All interested data are obtained in digital format with $1 \mathrm{~km} \times 1 \mathrm{~km}$ spatial resolution and are applied to a probabilistic model based on multiple logistic regression method, to evaluate the landslide hazard probability. Finally the results of landslide hazard probability are portrayed in a $1 \mathrm{~km} \times 1 \mathrm{~km}$ resolution map showing the landslide hazard (hazard index).

\subsection{Hydraulic factors}

Hydraulic gradient is an affective property for initiation of landslides. Hydraulic gradient is defined as the rate of change of hydraulic head per unit distance in a particular direction. Increase of hydraulic gradient in slope areas leads landslides (Moriwaki et al., 2006). Change in hydraulic gradient as a result of infiltration of rainfall is used as the main parameter to reflect the hydraulic condition in this study. The hydraulic gradient $(\Delta h / L)$ is derived from the phreatic line obtained by unsaturated infiltration analysis based on Richards equation (Richards, 1931; Ross, 1990), using soil data, slope angle and rainfall as the main input data as shown in Fig. 1. The infiltration analysis is used to estimate the hydraulic gradient as described in the following sections.

\subsubsection{Infiltration analysis}

Unsaturated infiltration analysis is used to obtain the change in hydraulic gradient due to rainfall $(\Delta h / L$ in Fig. 1). In addition to rainfall data, soil type data and slope angle data are used for the infiltration analysis, which are obtained from the National Land Information data (2001) published by Japanese Geographical Survey Institute, and Japanese Ministry of Land Infrastructure, Transport and Tourism. 
The governing equations and estimation steps for the infiltration analysis are as follows:

First the water volume content $\theta$ can be estimated as

$$
\frac{\partial \theta}{\partial t}=-\left(\frac{\partial V_{x}}{\partial x}+\frac{\partial V_{z}}{\partial z}\right)
$$

Where $\theta$ is the water volume content, $t$ is time interval, $V_{x}$ is the velocity in horizontal direction, and $V_{z}$ is the velocity in vertical direction.

The flow velocities $\left(V_{x}\right.$ and $\left.V_{z}\right)$ are obtained by of Darcy's equation (Eq. 2).

$$
\begin{aligned}
& V_{x}=-K_{x} \frac{\partial h}{\partial x} \\
& V_{z}=-K_{z} \frac{\partial h}{\partial z}
\end{aligned}
$$

Where $h$ is the total hydraulic head, $K_{x}$ is the unsaturated hydraulic conductivity in horizontal direction and $K_{z}$ is the unsaturated hydraulic conductivity in vertical direction.

The total hydraulic head $h$ is the sum of the hydraulic pressure head $\psi$ and elevation head. The elevation head can be estimated using horizontal and vertical length components ( $L_{x}$ and $L_{z}$ ), as $-L_{x} \sin \alpha-L_{x} \cos \alpha$

Therefore total head is

$h=\psi-L_{x} \sin \alpha-L_{z} \cos \alpha$

Combining Eqs. (1), (2) and (3), two-dimensional hydraulic head can be obtained as (Richards, 1931)

$$
\begin{aligned}
& C \frac{\partial \psi}{\partial t}=\frac{\partial}{\partial x}\left(K_{x} \frac{\partial \phi}{\partial x}\right)+\frac{\partial}{\partial z}\left(K_{z} \frac{\partial \phi}{\partial z}\right) \\
& C \frac{\partial \psi}{\partial t}=\frac{\partial}{\partial x}\left(K_{x} \frac{\partial \psi}{\partial x}-K_{x} \sin \alpha\right)+\frac{\partial}{\partial z}\left(K_{z} \frac{\partial \psi}{\partial z}-K_{z} \cos \alpha\right)
\end{aligned}
$$

Where $C,(C(\psi)=\partial \theta / \partial \psi)$ is the specific moisture capacity. Specific moisture capacity $C$ can be obtained by the gradient of the soil moisture characteristic curves (Gosh, 1980; Ahuja et al., 1985) and the corresponding values for soil types which are commonly available in Japan are obtained from the soil moisture characteristic curves developed by Kawakami (2003).

To solve this equation, two relationships have been used.

1. Relationship between unsaturated hydraulic conductivity $K$ and water volume content $\theta$

$$
\begin{aligned}
& K_{x}=K s_{x}\left(\frac{\theta-\theta_{\mathrm{r}}}{\theta_{\mathrm{s}}-\theta_{\mathrm{r}}}\right)^{\beta} \\
& K_{z}=K s_{z}\left(\frac{\theta-\theta_{\mathrm{r}}}{\theta_{\mathrm{s}}-\theta_{\mathrm{r}}}\right)^{\beta}
\end{aligned}
$$

Where $\beta$ is a soil characteristic value
2. Relationship between pressure head $\psi$ and water volume content $\theta$ (Bruseart, 1968).

$$
\theta=\left(\theta_{\mathrm{r}}-\theta_{\mathrm{s}}\right)\left(\frac{\psi^{\prime}}{\psi_{0}}+1\right) \exp \left(-\frac{\psi^{\prime}}{\psi_{0}}\right)+\theta_{\mathrm{r}}
$$

Where $\theta_{\mathrm{s}}$ is the saturation water volume content, $\theta_{\mathrm{r}}$ is the residual water volume content and $K_{\mathrm{S}}$ is the unsaturated hydraulic conductivity. These parameters can be obtained from the literature (Kawakami, 2003). Four soil types (gravel, sand, silt and clay) are taken into account for the infiltration analysis and Table 1 shows the properties of each soil type.

Relationships expressed by Eqs. (5) and (6) are used to solve Eqs. (2), (3) and (4), where $\psi_{0}$ is used as the initial condition (initial pressure) and $\psi^{\prime}$ is used as the saturated condition (saturated pressure). The convergent value of hydraulic head is used to estimate the hydraulic gradient as $\Delta h / L$. The estimated hydraulic gradient will then be used as the main input to the landslide probability model.

\subsubsection{Extreme precipitation and return period}

Extensive records of landslide activity in Japan show that, landslide prediction is closely related to the probability of exceeding threshold values of precipitation. Therefore, extreme precipitation events and the return period of extreme precipitation are in the main interest in this evaluation.

Extreme precipitation of several return periods (5 years, 30 years and 100 years) are estimated by analyzing recorded maximum $24 \mathrm{~h}$ precipitation data for 20 years (1980-2000), obtained from 1024 AMeDAS (Automated Meteorological Data Acquisition System) meteorological observation stations. For the frequency analysis of the return period of extreme precipitations, GEV (Generalized Extreme Value) distribution function is used as probability distribution, and PWM (Probability Weight Moment) - method is used for universal prediction method.

As the first step, PWM-method is used to obtain the probability weight moment $\beta$ as follows

$$
\left\{\begin{array}{l}
\beta_{0}=\frac{1}{N} \sum_{j=1}^{N} x_{(j)} \\
\beta_{1}=\frac{1}{N(N-1)} \sum_{j=1}^{N}(j-1) x_{(j)} \\
\beta_{2}=\frac{1}{N(N-1)(N-2)} \sum_{j=1}^{N}(j-1)(j-2) x_{(j)}
\end{array}\right.
$$

Where $N$ is Number of sample data, $j$ is the rank, $x_{(j)}$ is the values of smaller rank in sample data, which used the maximum daily rainfall in AMeDAS data set from 1980 to 2000. The product moment $\lambda$ is obtained based on Probability weight moment $\beta$.

$\left\{\begin{array}{l}\lambda_{1}=\beta_{0} \\ \lambda_{2}=2 \beta_{1}-\beta_{0} \\ \lambda_{3}=6 \beta_{2}-6 \beta_{1}+\beta_{0}\end{array}\right.$ 
Table 1. Properties of four soil types used for infiltration analysis.

\begin{tabular}{lcccc}
\hline $\begin{array}{l}\text { Soil } \\
\text { type }\end{array}$ & $\begin{array}{c}\text { Hydraulic } \\
\text { conductivity } \\
(\mathrm{cm} / \mathrm{s})\end{array}$ & $\begin{array}{c}\text { Saturation } \\
\text { water volume } \\
\text { content }\end{array}$ & $\begin{array}{c}\text { Residue } \\
\text { water volume } \\
\text { content }\end{array}$ & $\begin{array}{c}\text { Soil } \\
\text { characteristic } \\
\text { value }\end{array}$ \\
\hline Gravel & $1 \times 10^{-2}$ & 0.30 & - & 3 \\
Sand & $1 \times 10^{-3}$ & 0.40 & - & 3 \\
Silt & $1 \times 10^{-4}$ & 0.45 & 0.05 & 5 \\
Clay & $1 \times 10^{-5}$ & 0.50 & 0.10 & 20 \\
\hline
\end{tabular}

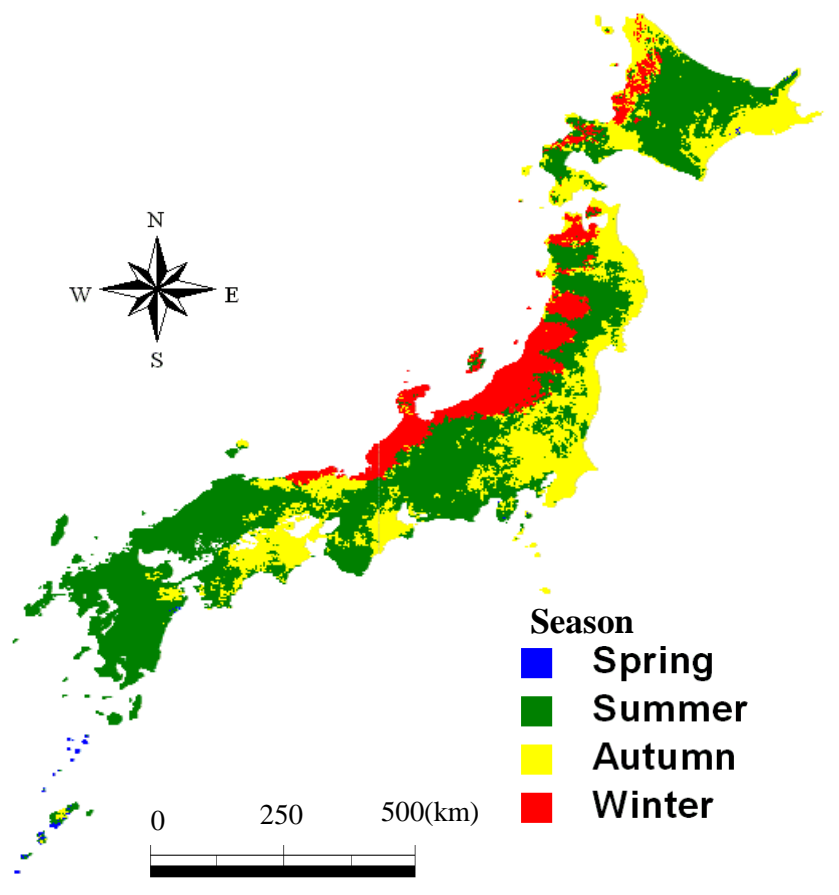

Fig. 2. Distribution of the annual maximum daily rainfall.

Population parameter $k$ is obtained combining the Probability weight moment $\beta$ and product moment $\lambda$ as follows;

$k=7.8590\left(\frac{2 \lambda_{2}}{\lambda_{3}+3 \lambda_{2}}-\frac{\ln (2)}{\ln (3)}\right)+2.9554\left(\frac{2 \lambda_{2}}{\lambda_{3}+3 \lambda_{2}}-\frac{\ln (2)}{\ln (3)}\right)(9)$

The scale parameter $a$ and location parameter $c$ are obtained using the population parameter $k$ and product moment $\lambda$.

$$
\left\{\begin{array}{l}
a=\frac{k \lambda_{2}}{\left(1-2^{-k}\right) \Gamma(1+k)} \\
c=\lambda_{1}-\left(\frac{a}{k}\right)[1-\Gamma(1+k)]
\end{array}\right.
$$

The CDF (Cumulative Distribution Function) $F(x)$ of the GEV distribution is obtained from the following equation based on population parameter $k$, scale parameter $a$ and location parameter $c$.

$F(x)=\exp \left\{-\left[1-\left(\frac{k}{a}\right)(x-c)\right]^{1 / k}\right\}$
Extreme heavy rainfall of return period $T$ years is obtained by the following equation (Eq. 12) which is the inversion to Eq. (11).

$\left\{\begin{array}{l}x_{T}=c+\left(\frac{a}{k}\right)\left\{1-[-\ln (p)]^{k}\right\} \\ p=1-(1 / T)\end{array}\right.$

Where $T$ is the return period, and $p$ is non exceed probability.

To evaluate the spatial distribution of maximum precipitation in each return period, a linear regression analysis is used to develop the relationship between the extreme precipitation data and annual mean precipitation data. Annual mean precipitation data are obtained from the precipitation data base of Meteorological department of Japan, which is called "Mesh Climate Value 2000" (Japanese Meteorological Business Support Center, 2002). To apply the linear regression analysis the inverse distance weighted method and the Tissen method are used to interpolate precipitation values.

Since rainfall and related change in hydraulic gradient are the main consideration in this study, the winter precipitation in form of snowfall should not be taken into account. Therefore, only rainfall is considered to estimate the extreme precipitation for each return period. Widely used $2{ }^{\circ} \mathrm{C}$ threshold is used to seperate the rainfall and snowfall (Singh and Bengtsson, 2005; Kazama et al., 2008) and the regression analysis conducted separately selecting only rainfall events and omitting snowfall events.

Therefore, different regression coefficients should be estimate for different seasons (Ushiyama and Takara, 2003). Considering that the spring rainfalls are from March to May; the summer rainfalls are from June to August; the autumn rainfalls are from September to November; and the winter rainfalls are in warm days (days with average temperature more than $2{ }^{\circ} \mathrm{C}$ ) from December to February, Fig. 2 shows the distribution of the annual maximum daily rainfall according to the season. Mountains areas in western side of Japan (Japan Sea side) receive the maximum rainfall during the winter. Rest of the areas receives the maximum rainfall during the summer and autumn. Only south islands of Japan receive the maximum rainfall in the spring. Therefore summer and spring rainfalls are grouped to a common category for the analysis purpose and separate regression analysis are 

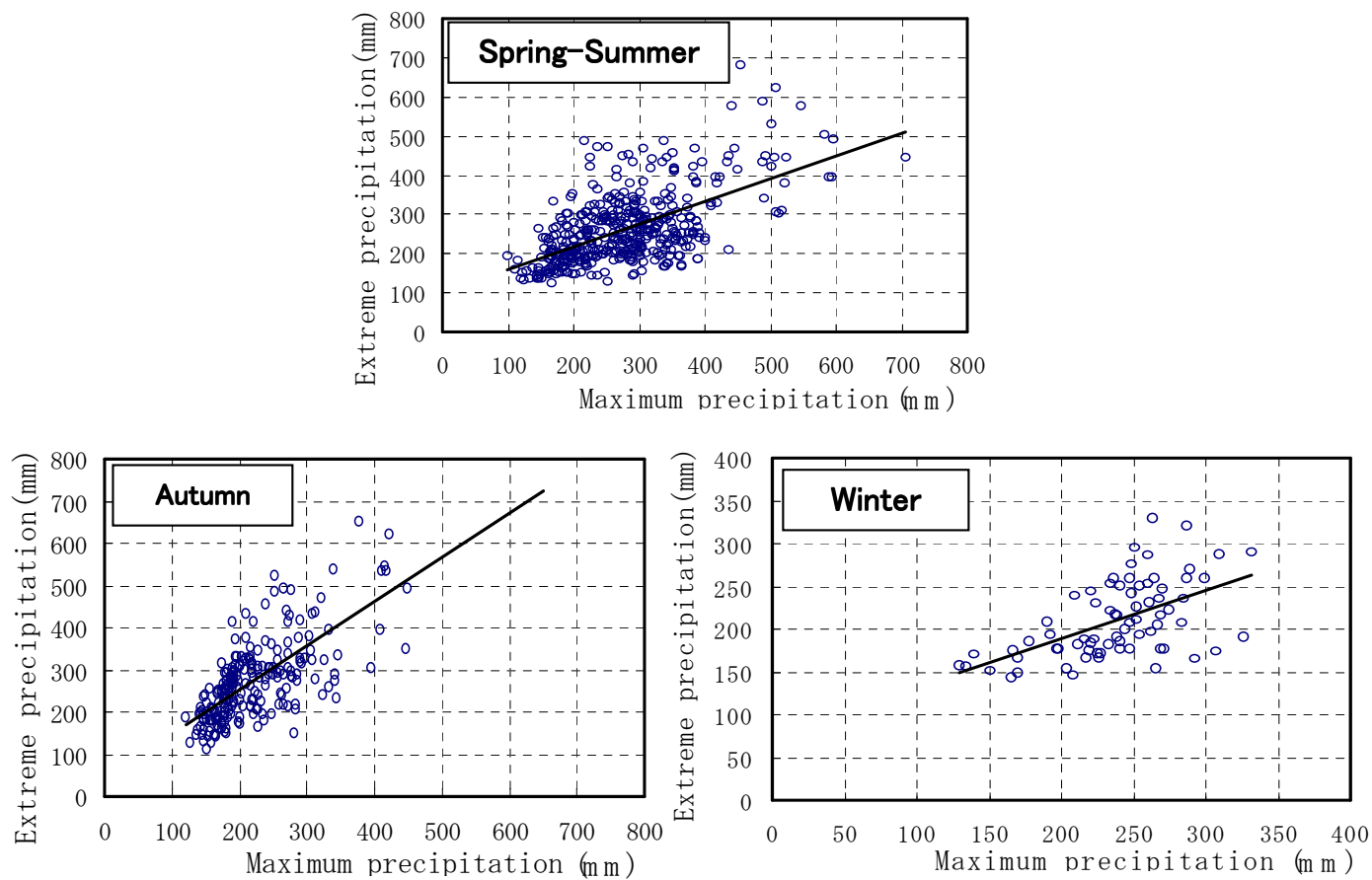

Fig. 3. Relationships between maximum monthly rainfall and the extreme precipitation for 30 years return period in each season.

carried out for areas having their maximum rainfall in autumn, winter, and spring + summer.

Figure 3 shows the relationships between maximum monthly precipitation in each season and the extreme precipitation for 30 years return period. It explains that the regression line between maximum monthly precipitation and the extreme precipitation changes seasonally. Therefore regression analysis is carried our for three selected return periods (5 years, 30 years and 100 years) considering each seasonal data separately. Figure 4 shows the distribution of the extreme precipitation over Japan in 5 years, 30 years and 100 years return periods. This map illustrates that maximum precipitation is lower in Japan Sea side as winter snowfalls are removed from the database. Pacific Ocean side of the Japan receives the highest extreme precipitations. Table 2 summarizes the correlation between maximum monthly precipitation in each season and the extreme precipitation of 5 years, 30 years and 100 years return period. The estimated maximum precipitations are used as the main hydraulic input for the infiltration analysis.

\subsection{Topographic factor - relief energy}

Geographical properties of the slope effectively affect the probability of landslide hazards. To represent geographical features, the main topographic factor, relief energy is utilized as an input for probability model to describe the elevation differences in the area. Relief energy is defined as the elevation difference between the highest location and lowest location. Relief energy is an index that could show the com-

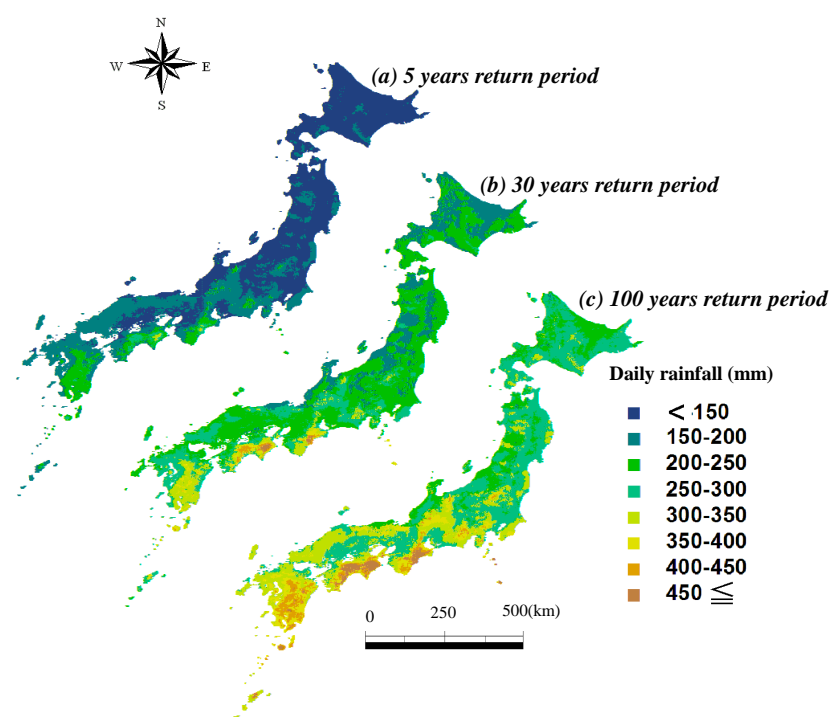

Fig. 4. Distribution of the extreme precipitation in 5 years, 30 years and 100 years return periods.

plexity of geographical features considering the active development of landform (Derbyshire et al., 1995; Crescenzo and Santo, 2005). Therefore, in this study relief energy is defined as the elevation difference between the highest and the lowest elevation in each grid cell and the relief energy for each $1 \mathrm{~km} \times 1 \mathrm{~km}$ resolution grid cell is estimated using the digital elevation model (DEM) data of the study area obtained from National-land information database (2001). 
Table 2. Correlation between maximum monthly precipitation and the extreme precipitation of 5 years, 30 years and 100 years return period.

\begin{tabular}{llccc}
\hline \multirow{2}{*}{ Return period } & Season & Correlation coefficient & \multicolumn{2}{c}{ Regression } \\
& & & Coefficient & Intercept \\
\hline \multirow{3}{*}{5 years } & Spring, Summer & 0.70 & 0.35 & 42.98 \\
& Autumn & 0.77 & 0.60 & 26.68 \\
& Winter & 0.71 & 0.36 & 39.91 \\
\hline \multirow{3}{*}{30 years } & Spring, Summer & 0.68 & 0.49 & 85.96 \\
& Autumn & 0.80 & 0.94 & 34.42 \\
& Winter & 0.67 & 0.51 & 67.43 \\
\hline \multirow{3}{*}{100 years } & Spring, Summer & 0.65 & 0.65 & 118.76 \\
& Autumn & 0.70 & 1.19 & 52.11 \\
& Winter & 0.62 & 0.64 & 89.24 \\
\hline
\end{tabular}

Table 3. Summary of the results of the multiple logistic regression analysis.

\begin{tabular}{llrrr}
\hline Geological features & Regression factor & Hydraulic gradient $\sigma_{\mathrm{h}}$ & Relief energy $\sigma_{\mathrm{r}}$ & Intercept $\sigma_{0}$ \\
\hline \multirow{3}{*}{ Colluviums } & Coefficient $\sigma$ & 12.39 & 0.06 & -28.21 \\
& Significance probability & 0.03 & 0.04 & 0.05 \\
& Standard regression coefficient & 2.16 & 1.76 & - \\
\hline \multirow{3}{*}{ Neogene sedimentary rocks } & Coefficient $\sigma$ & 11.56 & 0.05 & -29.98 \\
& Significance probability & 0.03 & 0.03 & 0.04 \\
& Standard regression coefficient & 1.99 & 1.24 & - \\
\hline \multirow{5}{*}{ Paleogene sedimentary rocks } & Coefficient $\sigma$ & 10.78 & 0.04 & -30.24 \\
& Significance probability & 0.05 & 0.04 & 0.05 \\
& Standard regression coefficient & 1.65 & 1.01 & - \\
\hline \multirow{3}{*}{ Granites } & Coefficient $\sigma$ & 9.53 & 0.05 & -31.12 \\
& Significance probability & 0.04 & 0.05 & 0.04 \\
& Standard regression coefficient & 0.99 & 0.89 \\
\hline
\end{tabular}

\subsection{Geological factors}

Four mostly common geological formations are considered as geological parameters for the study; colluvium, Tertiary sedimentary rocks, and granites. Tertiary sedimentary rocks are divided to two subgroups as Neogene sedimentary rocks and Paleogene sedimentary rocks by considering the different geological formations. Geological formation data are also obtained from the digital national land information database (National-land information data, 2001).

\subsection{Landslide hazard probability model}

Landslide Hazard is expressed as probability of occurrence within a reference period as a function of the spatial probability and the temporal probability (Westen, 2006; Zezere, 2000). In this study a stepwise logistic regression model is constructed to find the relations among landslide probability and the above mentioned physical parameters. The multiple logistic regression method is preferred for this analysis, since multiple logistic regressions allow forming a multivariate regression relation between a dependent variable and several independent variables. Also the logistic multiple regressions are easier to use for hazard analysis when there is a mixture of numerical and categorical regresses, because it includes procedures for generating the necessary dummy variables automatically (Hair et al., 1998). As many variables are categorized in this landslide analysis, multiple logistic regression analysis is used and the regressions are formulated in the form of regression coefficient. Since hydraulic gradient is used as one temporal variable, multiple logistic analyses are useful to use kinetic data and to simulate predicted future data and temporal changes. For each geological lithology type, the landslide hazard is described by the explaining variables such as hydraulic gradient and relief energy. The landslide hazard probability responding such variables is constructed as a logistic curve with multiple regressions, 

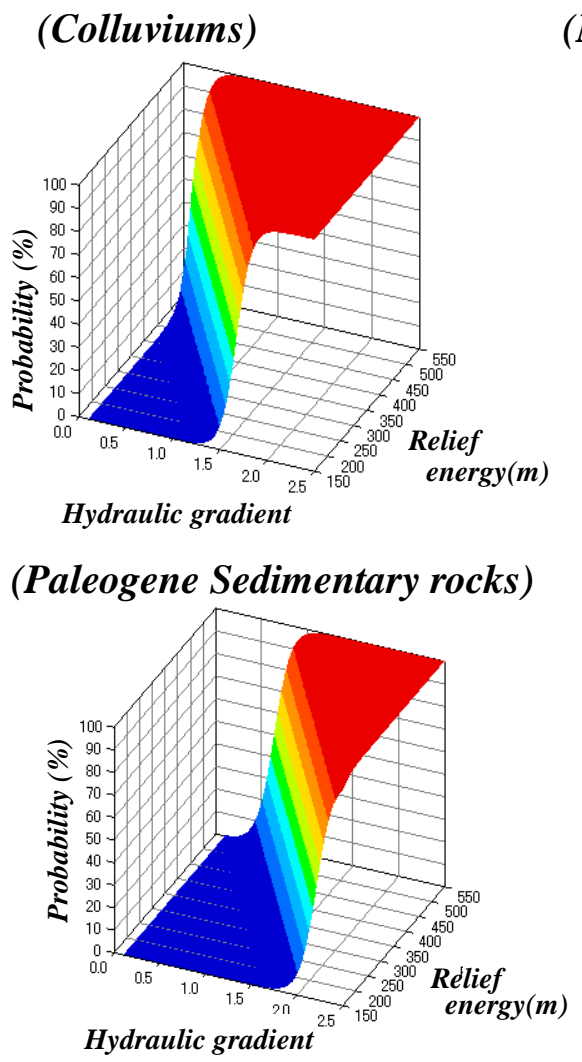
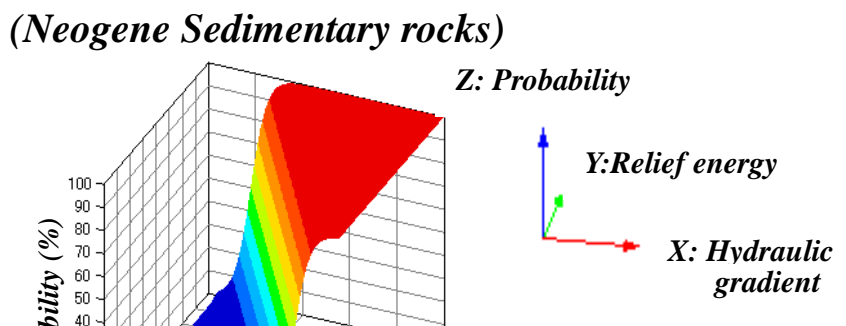

Fig. 5. Developed logistic curves for four geological properties.

as expressed in the following equations.

$$
\begin{aligned}
& \log \left(\frac{P}{1-P}\right)=\sigma_{0}+\sigma_{\mathrm{h}} \times \text { hyd }+\sigma_{\mathrm{r}} \times \text { relief } \\
& P=\frac{1}{1+\exp \left[-\left(\sigma_{0}+\sigma_{\mathrm{h}} \times \text { hyd }+\sigma_{\mathrm{r}} \times \text { relief }\right)\right]}
\end{aligned}
$$

Where $P$ is the probability of landslide occurrence, $\sigma_{0}$ is the interception, $\sigma_{\mathrm{h}}$ is the coefficient of hydraulic gradient, $\sigma_{\mathrm{r}}$ is the coefficient of relief energy, "hyd" is the hydraulic gradient, and "relief" is the relief energy.

The results of the multiple logistic regressions expressing the relationships among hydraulic gradient and relief energy for each geological formation are summarized in Table 3. As explained in above equations, probability of landslide occurrence for each geological formation depends on two explaining variables; hydraulic gradient and relief energy. The distribution of each geological pattern is able to affect the probability of landslide and distort the results because the geological features are not uniformly distributed over the area. Therefore, the probability analysis is separately constructed for four geological features: colluvium, Paleogene sedimentary rocks, Neogene sedimentary rocks, and granites. The developed logistic curves for selected four geological formations are presented in Fig. 5. The rising position (point that the probability $>0$ ) and the slope angle of the logistic curves could display the risk of geological feature. When the rising position is lower, it gives higher risk. Also when the slope is steep, it gives high risk. Therefore, Fig. 5 shows that colluvium geological formation shows the highest risk. Second highest is Neogene sedimentary rock. The least risk geological formation is granite. This order corresponds to the hardness of geological features. Then the developed probability model is applied to each $1 \mathrm{~km} \times 1 \mathrm{~km}$ grid cell employing the hydraulic, geological and geographical properties of each cell. This task has produced the assessment maps showing the distribution of landslide hazard probability over entire Japan.

\section{Results and discussion}

\subsection{Landslide hazard probability}

The results of the probability model, the spatial distribution of landslide hazard probability based on rainfall induced infiltration condition, geographical conditions and geological formations of the area are portrayed on landslide hazard probability maps using Geographic Information System (ARC/INFO-GIS). In order to evaluate the temporal changes, the probability is estimated for changing hydraulic factors using three different return periods of extreme precipitation; 


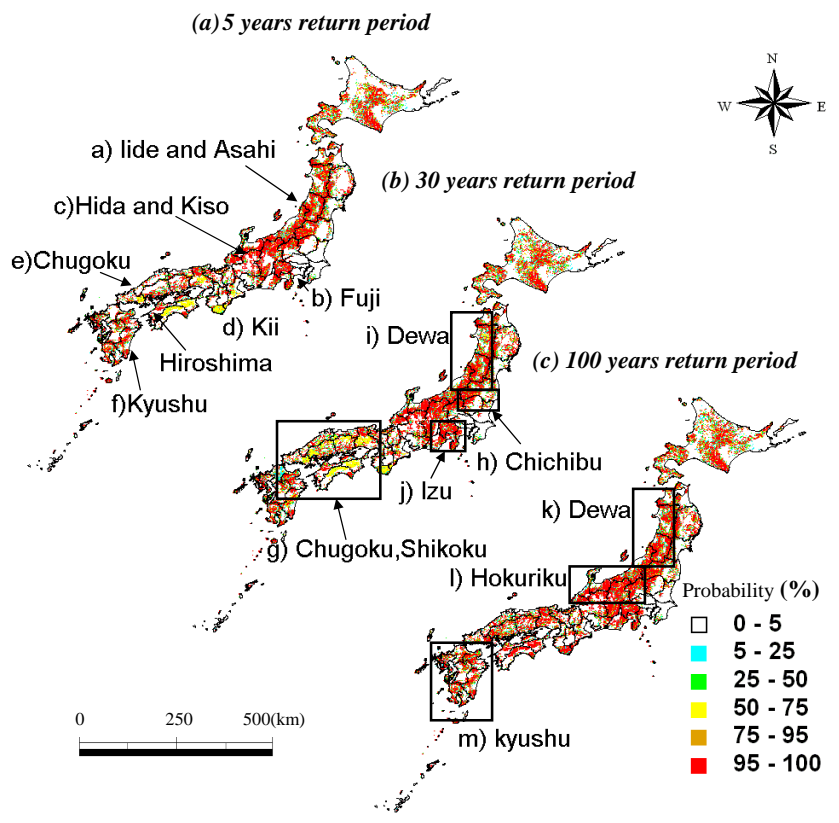

Fig. 6. Developed landslide hazard probability maps; (a) for extreme precipitation in 5 years return period, (b) for extreme precipitation in 30 years return period, (c) for extreme precipitation in and 100 years return periods.

5 years, 30 years, 100 years. The change of the return period could explain the temporal change of the landslide hazards probability. Landslide hazard probability according to the extreme precipitation for different return periods are highly important, because return period dictates the time frames and design guidelines for countermeasures and it also show the order of priority in mitigation processes and financial fund allocations.

The developed rainfall induced landslide hazard maps for 5 years, 30 years and 100 years return period are shown in Fig 6. They clearly separate the high risk and low risk areas. The regions where the landslide hazard probability is greater than $95 \%$ are marked as high risk areas. Overall, the mountain range on the Japan Sea side shows the highest landslide hazard probability. Especially steep mountain regions spread in these areas.

The most vulnerable areas are the areas having the largest landslide hazard probability in extreme precipitation of 5 years return period map. They are (as shown in Fig. 6a);

1. Iide and Asahi mountainous ranges

2. South east side of Mt. Fuji

3. Hida and Kiso mountainous ranges

4. South side of the Kii Mountains

5. South side of the Chugoku Mountains

6. South side of the Kyusyu Mountains
To understand the impacts of heavy precipitation conditions, landslide hazards probability maps for extreme precipitations in different return periods are compared. It shows that extreme precipitation in longer return periods make the situation more critical. Results considering extreme precipitation for 30 years return period and 5 years return period, the maps clearly show that the vulnerable areas further expand over whole Chugoku mountain region. Especially, remarkable increase can be observed over Shikoku region and in the Izu islands which show over $95 \%$ of landslide hazard probability for 30 years return period. The landslide hazard probability for extreme precipitation in 100 years shows that the vulnerable areas expand to the Dewa mountainous range and to the Hokuriku region. Especially, some additional areas of over 95\% probability are distributed in the southern part of the Kyushu mountain range.

These areas should be given priority for developing mitigations and countermeasures. Most of these high risk areas are relatively low populated areas. Therefore, the direct impacts on human lives and properties are less in most of the areas except in the Chugoku mountain range. Damage of human lives and public infrastructures due to landslides is one of the main problems in the south sides of the Chugoku mountain range abut to an urban area. The Hiroshima prefecture included in the Chugoku mountain range had landslides seven times since 1945 (in 1945, 1951, 1957, 1982, 1991, 1993, and 1999). The landslide hazard occurred in 1999 (29 June to 3 July in 1999) is a well known disaster in Japan. It leaded to develop landslide hazard preventive law (Cabinet paper on 28 March 2001, 2001). Our results also show that south side of the Chugoku mountain range is a high risky landslide prone area and it is one of the areas to allocate countermeasures for landslide disasters.

Even though population densities are comparatively low, all these mountain ranges are supplied with a large amount of infrastructure especially dams, reservoirs, highways and railways. Landslides in dam catchment areas bring huge amount of sediments to reservoirs and it leads to accumulate the sediment in the reservoirs. Also the sediment flow affects the water quality in the reservoirs. In the Chubu region which locates in the south east side of Mt. Fuji and the Hida and Kiso mountains, the sediment deposits in the reservoir are remarkable problem (Takemura, 1999). Therefore prediction of landslide- probability and early warning at the design stages of the reservoirs helps the proper management of reservoirs allowing high capacity of dead volume for sediment deposits in reservoirs located in landslide prone areas. Also it would be helpful for operational counter measures in these dams which predict high probability of extreme precipitation at a short cycle. Addition to the damages of reservoirs and dams, landslides damage the transportation infrastructures in these areas. Landslides lead to collapse of the roads, railways and bridges, block the roads and railways which cause serious traffic problems during heavy rainfall periods. 


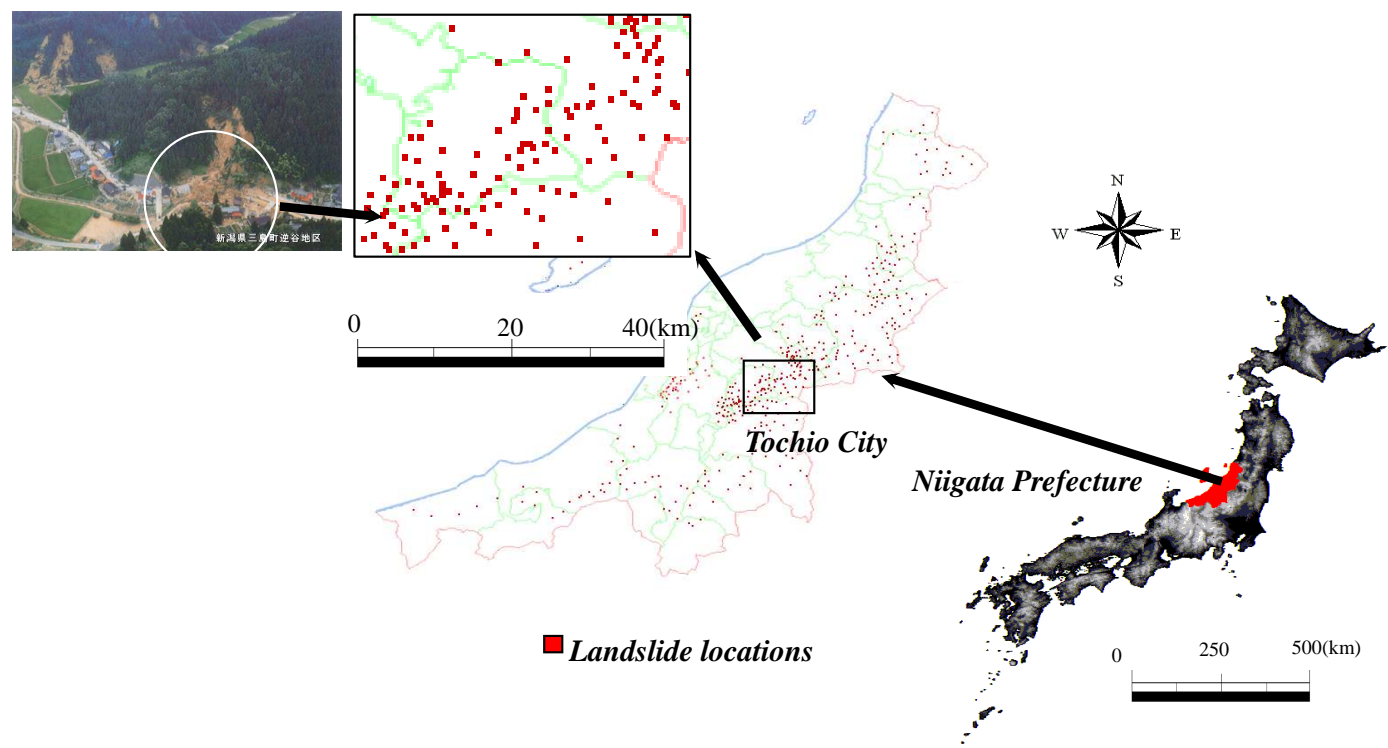

Fig. 7. Observed landslide locations in Tochio city.

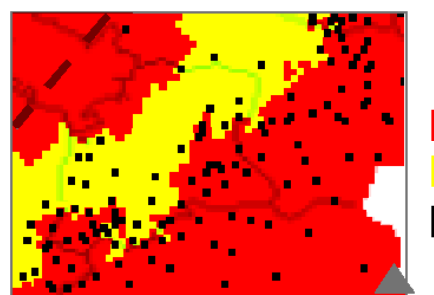

a) $95 \%$ threshold

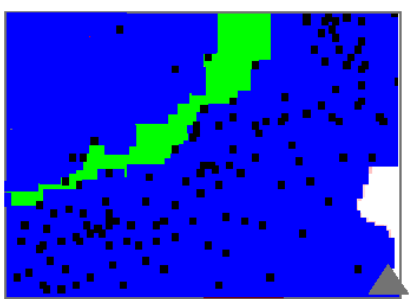

b) $80 \%$ threshold
Probability over 95\%

Probability less than 95\%

Landslide locations

Probability over $80 \%$

Probability less than $80 \%$

Landslide locations

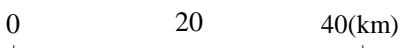

Fig. 8. Comparison of landslide hazard probability map and observed landslides in Tochio city.

\subsection{Model verification with historical landslide events}

A key assumption using the probabilistic approach is that the potential (occurrence possibility) of landslides will be comparable to the actual frequency of landslides. As independent validation of statistical models for landslide hazard assessment is very important (Remondo et al., 2003; Westen et al., 2003), in this study, we performed a model verification using recorded past landslide data.

Historical landslide hazard data for Tochio city, where 183 landslides were occurred in 2004, are used to compare the developed landslide hazard maps and actual landslides. Due to the downpour on 12 July 2000, 374 landslides were de- tected using aerial photographs over Niigata prefecture. Out of these, 183 disasters are concentrated in Tochio City. The downpour event recorded $422 \mathrm{~mm}$ of precipitation within $24 \mathrm{~h}$ in the AMeDAS observation station at Tochio city. This is the maximum extreme precipitation recorded in 530 years return period. Distribution of the detected landslide hazard areas taken from aerial photographs were converted to vector-type spatial landslide hazard map of $1 \mathrm{~km} \times 1 \mathrm{~km}$ resolution using the ARC/INFO GIS software (Yamagishi et al., 2004). Figure 7 shows the observed landslide locations in Tochio city. 

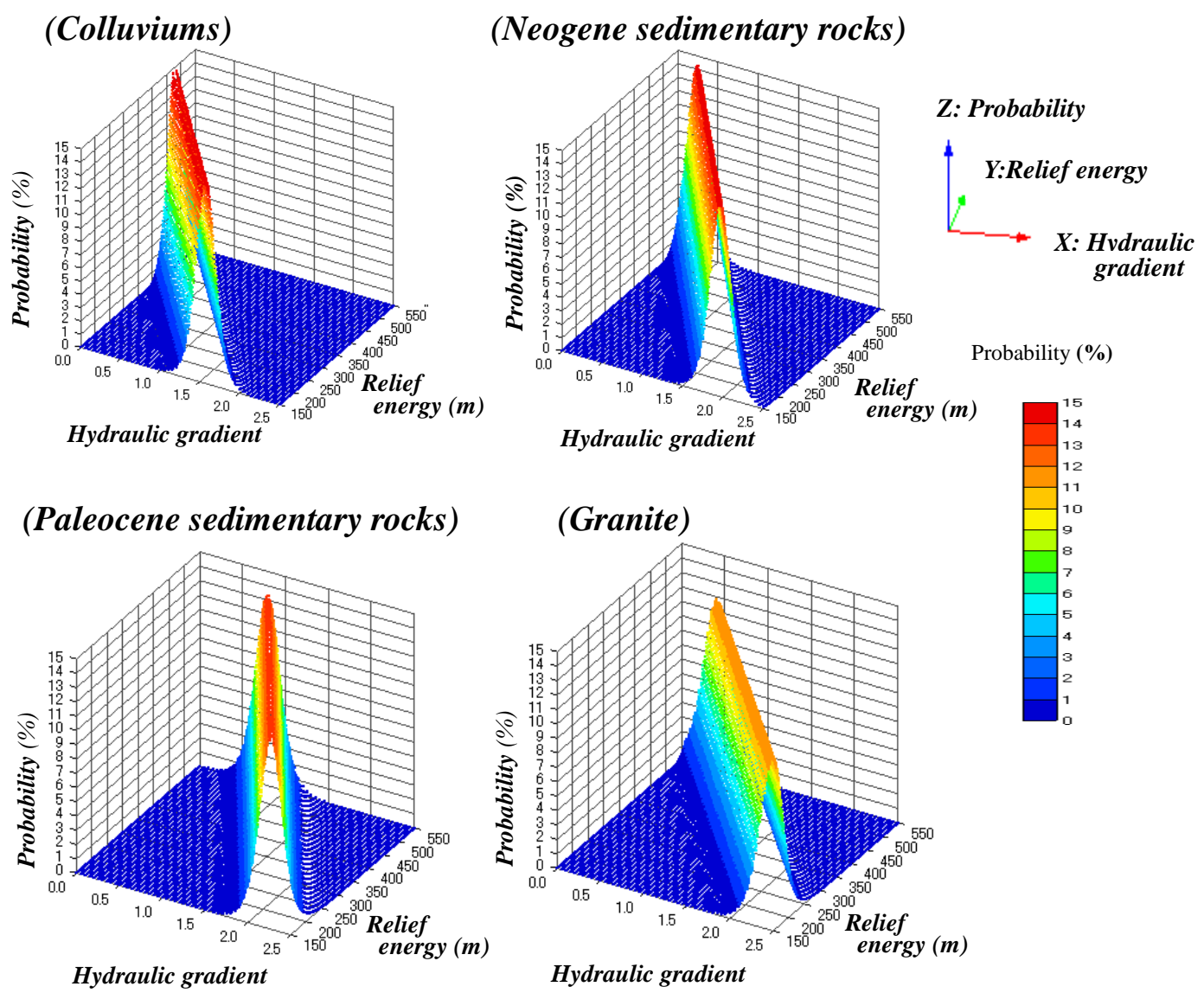

Fig. 9. Relationship between the change in landslide hazard probability and change in hydraulic gradient and relief energy for the four geological parameters.

Using the developed landslide hazard probability map, two main group of risk conditions are defined as "high risk areas" and "low risk areas". Areas having average landslide hazard probability of over $95 \%$ are categorized as "high risk areas" and areas having landslide hazard probability less than 95\% are categorized as "low risk areas". The observed 183 landslide locations are overlapped on landslide hazard probability map (Fig. 8a). It shows that most of the landslides (160 landslides) are occurred in high risk areas (where landslide hazard probability is over $95 \%$ ). Only few landslides (23 landslides) occurred in low risk areas, which show $88 \%$ agreement with the model results. When comparing the results based on geological properties, it shows that colluviums geological areas shows the best agreement with over $95 \%$ landslides are taken place in landslide risk areas. The agreement is not perfect in granite geological areas. This means that strong geological properties (such as granite), are well protective for landslide hazards (Table 4). If the threshold for "landslide risk areas" and "low risk areas" is changed to $80 \%$, Fig. $8 \mathrm{~b}$ shows that all observed landslides are located inside the "landslide risk areas". Therefore for management point of view, the areas with landslide hazard proba- bility with more than $80 \%$ should be taken into account when planning mitigation and countermeasures. Anyway as overall situation, the observed landslide records are well matches with the analytical results.

\subsection{Sensitivity analysis}

\subsubsection{Identification of sensitive parameters}

To investigate the sensitivity of the changes in hydraulic gradient and relief energy on the change in landslide hazard probability, a sensitivity analysis is conducted. Figure 9 illustrate the relationship between the change in landslide hazard probability and change in hydraulic gradient and relief energy for four geological parameters; colluvium, Paleogene sedimentary rocks, Neogene sedimentary rocks, and granites. Here the hydraulic gradient is changed by 0.01 intervals from 0 to 2.5 , and relief energy by $1 \mathrm{~m}$ intervals from $150 \mathrm{~m}$ to $550 \mathrm{~m}$. Figure 9 shows that change of probability highly depends on hydraulic gradient than on relief energy. Change in probability with relief energy (slope of the curve surface in Y-direction) is almost constant. While observing the change in probability for $150 \mathrm{~m}$ relief energy value, in the case of 
Table 4. Distribution of observed landslide locations and landslide hazard probability for Tochio city.

\begin{tabular}{lccc}
\hline Geographical property & $\begin{array}{c}\text { Number of observed } \\
\text { landslide locations }\end{array}$ & $\begin{array}{c}\text { Number of landslides } \\
\text { in risk areas }\end{array}$ & $\begin{array}{c}\text { Agreement } \\
\text { ratio }\end{array}$ \\
\hline All geological properties & 183 & 160 & $87.4 \%$ \\
Colluviums & 45 & 43 & $95.6 \%$ \\
Neogene sedimentary rocks & 77 & 66 & $85.7 \%$ \\
Paleogene sedimentary rocks & 38 & 34 & $89.5 \%$ \\
Granite & 23 & 17 & $73.9 \%$ \\
\hline
\end{tabular}

colluviums condition, the landslide hazard probability suddenly increases by $15 \%$ when hydraulic gradient changes from 1.2 to 1.5 relief energy. In the case of granite, this increment of landslide hazard probability is $12 \%$. Literature shows that $350 \mathrm{~m}$ relief energy is high appearance frequency in the mountainous ranges in Japan (Katsube, 2001). Therefore, $350 \mathrm{~m}$ relief energy is an important value in discussion. Change in probability with change in hydraulic gradient for $350 \mathrm{~m}$ relief energy is presented in Fig. 10. It clearly shows that areas having colluviums geological conditions show the highest influence from hydraulic gradient and areas having granite geological conditions have the lowest influence from hydraulic gradient. In colluviums geological areas, only 0.3 of hydraulic gradient $(0.5-0.2)$ is able to change the landslide hazard probability by $16 \%$, and in granite geological areas, 0.5 of hydraulic gradient (1.5-1.0) is able to change the landslide hazard probability by $13 \%$.

\subsubsection{Sensitivity of the resolution of input data}

Based on the resolution of the available data (specially climate and geology data), the developed landslide hazard probability distribution maps are in $1 \mathrm{~km} \times 1 \mathrm{~km}$ resolution. This coarse resolution gives general information to identify high risk areas. It is necessary to conduct a detailed analysis in high probability areas using fine resolution data. Anyhow developing fine resolution maps is time and resources consuming task. Also the availability of necessary data in fine resolution is rare.

To identify the influence of data resolution on results, a fine resolution probability map $(50 \mathrm{~m} \times 50 \mathrm{~m}$ map) is developed for Niigata prefecture. Fine resolution data (soil data, geology data and topography data) is obtained from digital database called "Digital geographic map 50 m" (2006). Figure 11 shows the comparison of landslide hazard probability in $50 \mathrm{~m} \times 50 \mathrm{~m}$ (R50) fine resolution map and $1 \mathrm{~km} \times 1 \mathrm{~km}$ (R1000) coarse resolution map, for extreme precipitation in 100 years return period. It shows that the high risk areas (areas having landslide hazard probability more than $80 \%$ ) is almost same in both maps. As indicated in Fig. 11, both maps show the areas having more than $80 \%$ landslide hazard probability as;

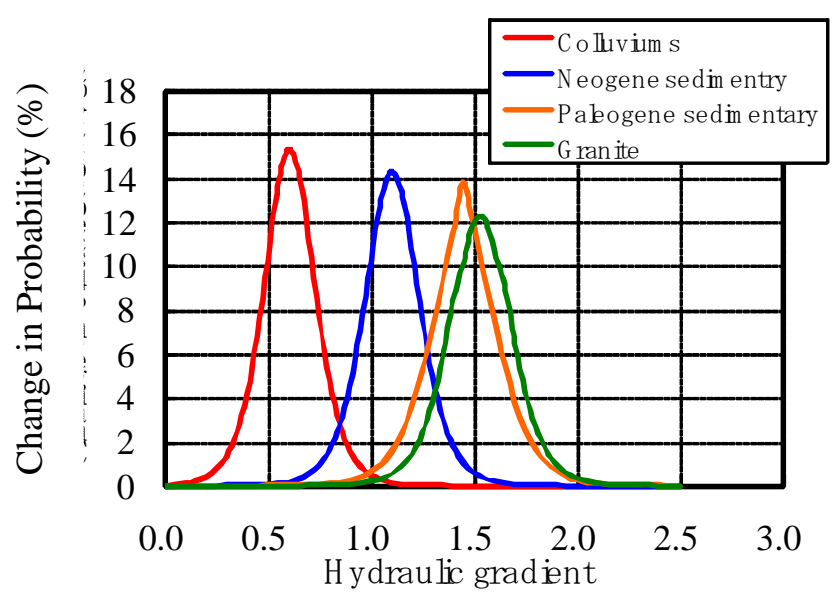

Fig. 10. Variation in probability Vs change in hydraulic gradient for $350 \mathrm{~m}$ relief energy.

1. West side of mountain range from Asahi to Iide

2. North west side of Uonuma hills

3. North west side of Mikuni mountain range

4. North side of Hida mountain range

However, several areas in the west side of the Niigata prefecture, show different results between two maps. R50 map depicts higher probability in some areas. Areas such as (e) Echigo plain and Asahi mountain range, (f) Hills in Tsugawa city and Aganogawa River basin, (g) Yahiko and Kakuta mountain range and (h) Sasagahara plateau show over $70 \%$ landslide hazard probability in R50 map, whereas they show about $40 \%$ landslide hazard probability in R1000 map. The reason is that R1000 map uses average geography and topography conditions while localized low and high elevation areas are not taken into account. These local high/low elevation areas become active in $\mathrm{R} 50$ resolution maps as they can be located in separate own grid cells in R50 resolution.

Taking the distribution of landslide hazard probability in R50 map into account, Fig. 12 shows the relationship between the probability in R1000 map and average of the 
Table 5. The definitions of landform types (source: National-land information data, 2001).

\begin{tabular}{lcll}
\hline Landform & Relief energy & Elevation & Geographical features \\
\hline Large relief mountain & Over $500 \mathrm{~m}$ & & \\
Middle relief mountain & $350 \mathrm{~m}-500 \mathrm{~m}$ & & Mountain \\
Small relief mountain & $200 \mathrm{~m}-350 \mathrm{~m}$ & & \\
Mountainside & $0 \mathrm{~m}-200 \mathrm{~m}$ & \multirow{2}{*}{ Over $200 \mathrm{~m}$} & \\
\cline { 2 - 3 } Large relief volcanic mountain & Over $500 \mathrm{~m}$ & & \\
Middle relief volcanic mountain & $350 \mathrm{~m}-500 \mathrm{~m}$ & & Volcanic mountain contains Quatemary deposits \\
Small relief volcanic mountain & $200 \mathrm{~m}-350 \mathrm{~m}$ & \\
Volcanic mountain side & $0 \mathrm{~m}-200 \mathrm{~m}$ & & \\
\hline Large relief hill & $100 \mathrm{~m}-200 \mathrm{~m}$ & $<200 \mathrm{~m}$ & Hillslopes \\
Small relief hill & $0 \mathrm{~m}-100 \mathrm{~m}$ & \\
\hline Plateau gravel & & River terrace of river or seaside \\
Plateau rocks & & River terrace of river or seaside \\
Alluvial fan & & Alluvial fan \\
Delta & & Delta \\
Natural levee & & Natural levee \\
\hline
\end{tabular}

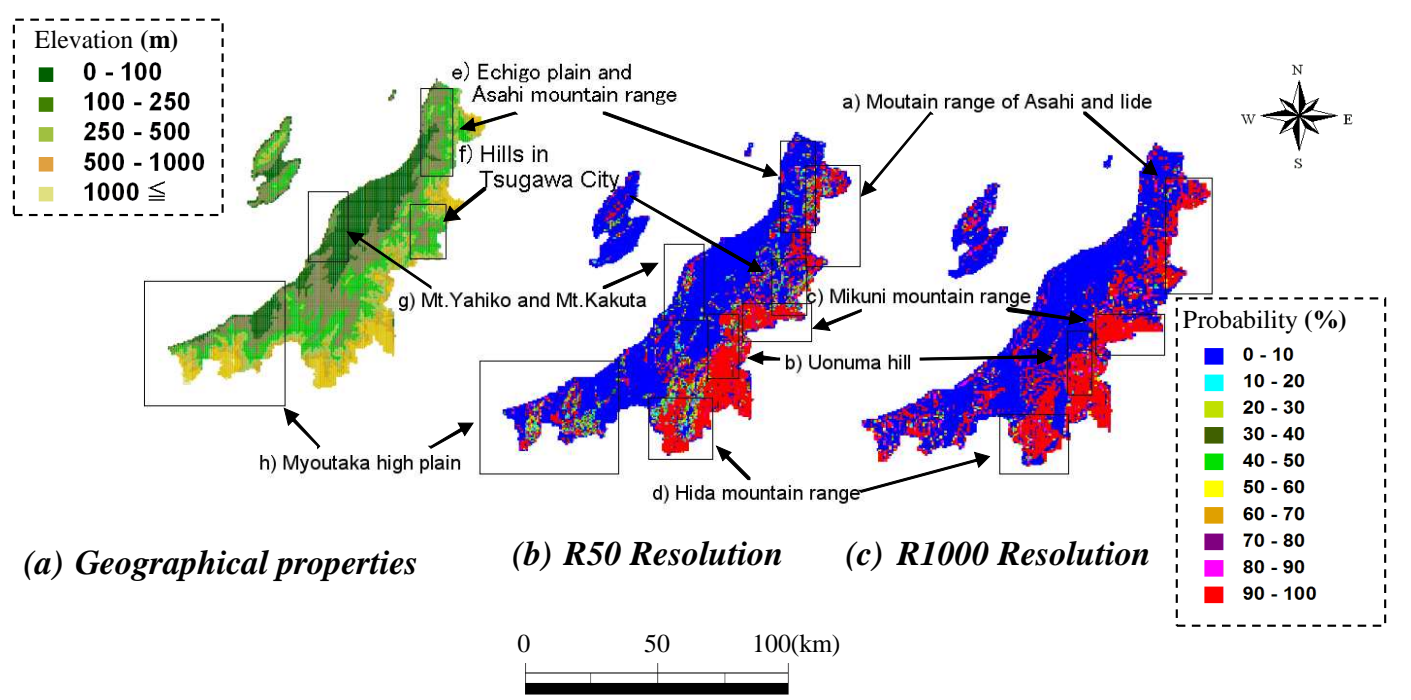

Fig. 11. Comparison of $50 \mathrm{~m} \times 50 \mathrm{~m}(\mathrm{R} 50)$ resolution map and $1 \mathrm{~km} \times 1 \mathrm{~km}(\mathrm{R} 1000)$ resolution map developed for Niigata prefecture (for extreme precipitation in 100 years).

probability of R50 map for Niigata prefecture. Average probability in $\mathrm{R} 50(50 \mathrm{~m} \times 50 \mathrm{~m})$ means average of the 400 probability values of 400 cells compatible with R1000 $(1 \mathrm{~km} \times 1 \mathrm{~km})$ area. Figure 12 depicts a strong correlation between two maps showing a correlation coefficient of 0.94 . Areas which have widely spread uniform geology, topography and hydraulic conditions show similar results for both R1000 and R50 maps whereas areas with heterogeneous conditions show deviations.

Figure 13 shows the comparison of average probability in coarse and fine resolution for different landform class. Table 5 explains the definitions of each landform class as de- fined by National-land information data (2001). According to this landform classification, most of high elevated areas (high mountains) show higher landslide probability, whereas low elevated areas (local hills and river deltas) show lower landslide probability in coarse resolution maps. Low lands highlight the higher landslide probability in fine resolution maps. Therefore high elevated areas (large relief mountains and large relief volcanic mountains) should be given special considerations during land developments and infrastructure development.

These results confirm that $\mathrm{R} 1000$ resolution is reasonably enough for analyze the landslide hazard probability for 


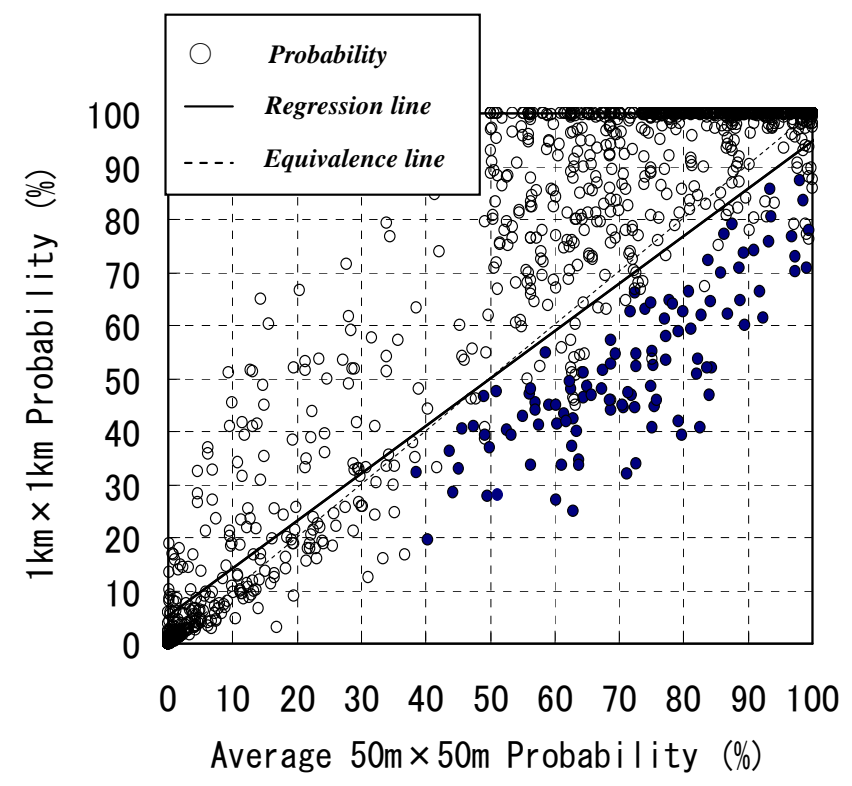

Fig. 12. Relationship between distributions of probability in R1000 map and average of the probability of R50 map.

management point of view. Therefore the developed R1000 maps can be used for management and decision making processes. The developed landslide hazard probability maps will assist authorities, policy makers and decision makers, who are responsible for infrastructural planning and development, as they can identify landslide-susceptible areas and thus decrease landslide damage through proper preparation.

\section{Conclusions}

Landslide hazards due to heavy rainfall are a common natural hazard in Japan. To evaluate the frequency and distribution of landslides hazards over Japan, this study uses a probabilistic model based on multiple logistic regression analysis, with particular reference to physical parameters such as hydraulic parameters (hydraulic gradient), geographical parameters (relief energy) and the four geological parameters (colluvium, Paleogene sedimentary rocks, Neogene sedimentary rocks, and granites) which are considered to be influential in the occurrence of landslides. All these physical data are obtained in digital format and the results of landslide hazard probability maps are portrayed in $1 \mathrm{~km} \times 1 \mathrm{~km}$ resolution digital maps.

The distribution of landslide hazard probability is estimated using the developed multiple logistic regression model and it shows the spatial and temporal distribution of landslide probability over Japan. Since the hydraulic parameter, hydraulic gradient is the main dynamic factor which includes the effect of heavy rainfall and their return period, the extreme precipitation of 5 years, 30 years, and 100 years return periods are used to represent the probability in different

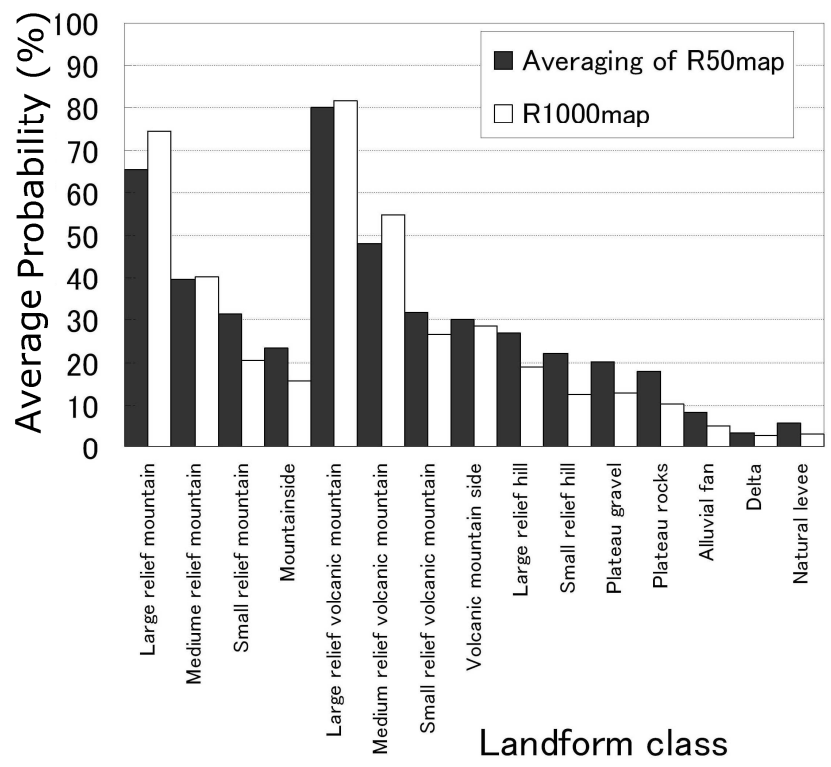

Fig. 13. Relationship between landform class and average probability for extreme precipitation in 100 years return period for coarse and fine resolution maps in Niigata Prefecture.

temporal scales. Results of the distribution of landslide hazard probability show that the highest landslide hazard probability exists in the mountain range on the western side of Japan (Japan Sea side) including Hida and Kiso mountainous, Iide and Asahi mountainous range, south east side of Mt. Fuji, south side of the Kii Mountains, south side of Chugoku mountainous range, south side of Kyusyu mountainous, Dewa mountainous range and the Hokuriku region.

To validate the developed probability maps, the collected past landslide hazard data for in Tochio city, where lot of landslide damages were occurred in 2004, are used to compare the developed landslide hazard maps and actual landslides. $95 \%$ probability threshold was used to separate the high risk and low risk areas. The validation proved that most of the landslides occurred in areas pointed out as high risk areas in landslide hazard probability maps, showing $88 \%$ agreement between model results and observed landslides. Further this study investigated the sensitivity of physical parameters on landslide hazards and confirmed that hydrological parameters (hydraulic gradient) are the most influencing factor in the occurrence of landslides. The sensitivity of resolution confirms that developed R1000 $(1 \mathrm{~km} \times 1 \mathrm{~km})$ maps are capable in assisting management decisions for infrastructural planning and development, as they can identify landslide-susceptible areas and thus decrease landslide damage through proper preparation.

Therefore while making land development activities and land use planning and decision making, landslide hazard maps are very useful to take appropriate decisions and subsequent measures for landslide prevention and mitigation. 
Acknowledgements. This research was funded by Global Environment Research Fund (GERF-S-4) of the Ministry of the Environment of Japan and Grant-in-Aid for Scientific Research from Japanese Society for Promotion of Science (JSPS) (Representative: Norihiro Izumi). Authors would like to thank for their generous financial assistances.

Edited by: E. Morin

\section{References}

Ahuja, L. R., Naney, J. W., and Williams, R. D.: Estimating soilwater characteristics from soimpler properties or limited data, Soil Sci. Soc. Am. J., 49, 1100-1105, 1985.

Aleotti P. and Chowdhury, R.: Landslide hazard assessment: summary review and new perspectives, B. Eng. Geol. Environm., 58, 21-44, 1999.

Atkinson, P. M. and Massari, R.: Generalized linear modelling of landslide susceptibility in the central Apennines, Italy, Comput. Geosci., 24, 373-385, 1998.

Cabinet paper-28 March 2001: Ministry of Land Infrastructure, Transport and Tourism, Japan, 2001.

Calcaterra, D., Gili, J. A., and Iovinelli, R.: Shallow landslides in deeply weathered slates of the Sierra de Collcerola (Catalonian Coastal Range, Spain), Eng. Geology, 50, 283-298, 1998.

Crescenzo, G. D. and Santo, A.: Debris slides - rapid earth flows in the carbonate massifs of the Campania region (Southern Italy): morphological and morphometric data for evaluating triggering susceptibility, Geomorphology, 66, 255-276, 2005.

Dai, F. C., Lee, C. F., Li, J., and Xu, Z. W.: Assessment of landslide susceptibility on the natural terrain of Lantau Island, Hong Kong, Environmental Geology, 40, 381-391, 2001.

Derbyshire, E., Van, T., Billard, A., and Meng, X.: Modeling the erosion susceptibility of landslide catchments in thick loess: Chinese variations on a theme by Jan de Ploey, CATENA, 25, 315331, 1995.

Digital geographic map $50 \mathrm{~m}$ : CD Rom published by Ministry of Land, Infrastructure, Transport and Tourism, Japan, 2006.

Fell, R., Corominas, J., Bonnard, C., Cascini, L., Leroi, E., and Savage, W. Z.: Guidelines for landslide susceptibility, hazard and risk zoning for land-use planning, Eng. Geology, 102(3-4), 99111, 2008.

Gokceoglu, C. and Aksoy, H.: Landslide susceptibility mapping of the slopes in the residual soils of the Mengen region (Turkey) by deterministic stability analyses and image processing techniques, Eng. Geology, 44, 147-161, 1996.

Gosh, R. K.: Estimation of soil moisture characteristics from mechanical properties of soils, Soil Sci. J., 130(2), 60-63, 1980.

Guzzetti, F., Reichenbach, P., Cardinali, M., Galli, M., and Ardizzone, F.: Probabilistic landslide hazard assessment at the basin scale, Geomorphology, 72, 272-299, 2005.

Hair, J. F., Anderson, R. E., Tatham, R. L., and Black, W. C.: Multivariate data analysis, 5 ed., Prentice-Hall, London, 1998.

Iida, T.: A stochastic hydoro-geomorphological model for sallow land sliding due to rainstorm, CATENA, 34(3, 4), 293-313, 1999.

Japanese Meteorological Business Support Center: CD data sources “Mesh Climate Value-2000", published by Japanese Meteorological Business support center, 2005.
Katsube, K.: Morphometric analysis of slope forms in Japanese mountains using $50 \mathrm{~m}$-DEMs, Japan Earth and Planetary Science Joint Meeting (CD-ROM), 2001.

Kawakami, F.: Soil Mechanics, Morikita publications, Tokyo, pp. 276, 2003 (in Japanese).

Kazama, S., Izumi, H., Sarukkalige, P. R., Nasu, T., and Sawamoto, M.: Estimating snow distribution over a large area and its application for water resources, Hydrol. Processes, 22, 2315-2324, 2008.

Kojima, H., Oobayashi, S., and Kitamura, R.: An application of satellite thermal infrared data in triggered - factor inverse estimation for identifying hazardous-slope composed of construction management and engineering, JSCE, 749, 99-110, 2003.

Lee, C. T., Huang, C. C., Lee, J. F., Pan, K. L., Lin, M. 1., and Dong, J. J.: Statistical approach to earthquake-induced landslide susceptibility, Eng. Geology, 100, 43-58, 2008.

Lee, S. and Min, K.: Statistical analysis of landslide susceptibility at Yongin, Korea, Environ. Geology, 40, 1095-1113, 2001.

Moriwaki, H., Yazaki, S., and Huang, W.: Simulation Analysis of rainfall induced groundwater flow in association with slope failure, J. Japan landslide society, 43(1), 9-19, 2006 (in Japanese).

Nagarajan, R., Roy, A., Kumar, A. V., Mukherjee, A., and Khire, M. V.: Landslide hazard susceptibility mapping based on terrain and climatic factors for tropical monsoon regions, B. Eng. Geol. Environ., 58(4), 275-287, 2000.

National-land information data,: Ministry of Land, Infrastructure, Transport and Tourism, http://nlftp.mlit.go.jp/ksj/old/cgi-bin/_ kategori_view.cgi, 2001.

Ohlmacher, G. C. and Davis, J. T.: Using multiple logistic regression and GIS technology to predict landslide hazard in North Kansas, Eng. Geology, 69, 331-343, 2003.

Okimura, T. and Ichikawa, T.: A delineation method for probable mountain slope failures by a digital land form model, JSCE, 358, 69-75, 1985.

Refice, A. and Capolongo, D.: Probabilistic modeling of uncertainties in earthquake-induced landslide hazard assessment, Comput. Geosci., 28, 735-749, 2002.

Remondo, J., González, A., Ramón, J., Cendrero, A., Fabbri, A., and Chung, C. J. F.: Validation of landslide susceptibility maps: examples and applications from a case study in Northern Spain, Natural Hazards, 30, 437-449, 2003.

Richard, D., Angelo, C., and Stefan, J.: Databases and GIS for landslide research in Europe, Geomorphology, 15, 227-239, 1996.

Ross, P. J.: Efficient Numerical Methods for Infiltration Using Richards' Equation, Water Resour. Res., 26, 279-290, 1990.

Shou, K., Chen, Y., and Liu, H.: Hazard analysis of Li-shan landslide in Taiwan, Geomorphology, 103/1, 143-153, 2009.

Singh, P. and Bengtsson, L.: Impact of warmer climate on melt and evaporation for the rainfed, snowfed and glacierfed basins in the Himalayan region, J. Hydrol., 300, 140-154, 2005.

Takemura, K.: Study on prediction and factors of runoff sediment yield, Journal of Hydraulics, coastal and environments engineering, JSCE, 47, 101-109, 1999.

Tarolli, P. and Tarboton, D. G.: A new method for determination of most likely landslide initiation points and the evaluation of digital terrain model scale in terrain stability mapping, Hydrol. Earth Syst. Sci., 10, 663-677, doi:10.5194/hess-10-663-2006, 2006.

Ushiyama, M. and Takara, K.: Relationship between warm season and highest hourly and daily precipitation based AMeDAS data, 
J. Jpn. Soc. Hydrol. Water Resour., 13-4, 368-374, 2003.

Westen, C. J., Rengers, N., and Soeters, R.: Use of geomorphological information in indirect landslide susceptibility assessment, Natural Hazards, 30, 399-419, 2003

Westen, C. J., Asch, T. W. J., and Soeters, R.: Landslide hazard and risk zonation-why is it still so difficult?, B. Eng. Geology Environ., 65/2, 167-184, 2006.

Wu, W. and Sidle, R. C.: A distributed slope stability model for steep forested basins, Water Resour. Res., 31, 2097-2110, 1995.

Xie, M., Tetsuro, E., Qiu, C., and Jia, L.: Spatial three-dimensional landslide susceptibility mapping tool and its applications, Earth Sci. Frontiers, 14, 73-84, 2007
Yamagishi, H., Ruruseged, A., Ootani, S., and Kato, K.: Study on research method and database due to sediment hazard, Research report on Japan construction information centre, JACIC, pp. 27, 2004.

Yilmazer, I, Yilmazer, O., and Saraç, C.: Case history of controlling a major landslide at Karandu, Turkey, Eng. Geology, 70, 47-53, 2003.

Zêzere, J. L.: Landslide susceptibility assessment considering landslide typology. A case study in the area north of Lisbon (Portugal), Nat. Hazards Earth Syst. Sci., 2, 73-82, doi:10.5194/nhess2-73-2002, 2002.

Zolfaghari, A. and Heath, A. C.: A GIS application for assessing landslide hazard over a large area, Comput. Geotechnics, 35, 278-285, 2008. 